\title{
Spatial variability of soil aggregate stability at the scale of an agricultural region in Tunisia
}

Mohamed Annabi a*, Damien Raclot ${ }^{b, c}$, Haithem Bahri ${ }^{d}$, Jean Stephane Bailly ${ }^{e}$, Cecile Gomez $^{b}$, Yves Le Bissonnais ${ }^{f}$

a National Agricultural Research Institute of Tunisia, Carthage University, Agronomy Lab, Hédi Karray Street, Ariana 2049

${ }^{\mathrm{b}}$ IRD, UMR LISAH, Laboratoire d'étude des Interactions Sol-Agrosystème-Hydrosystème, 2 place Viala, Montpellier 34060, France

${ }^{\mathrm{c}}$ Institut Agronomique \& Vétérinaire Hassan II, Madinat Al Irfane, Rabat, Morocco

${ }^{\mathrm{d}}$ National Institute for Research in Rural Engineering, Water and Forestry of Tunisia, Carthage University, Hédi Karray Street, Ariana 2049

${ }^{e}$ AgroParisTech, UMR LISAH, Laboratoire d'étude des Interactions Sol-AgrosystèmeHydrosystème, 2 place Viala, Montpellier 34060, France

f INRA, UMR LISAH, Laboratoire d'étude des Interactions Sol-Agrosystème-Hydrosystème, 2 place Viala, Montpellier 34060, France

\section{* Corresponding author}

E-mail addresses: mannabi@gmail.com (M. Annabi), damien.raclot@ird.fr (D. Raclot), haithem.bahri@gmail.com (H. Bahri), bailly@agroparistech.fr (J.S. Bailly), cecile.gomez@ird.fr (C. Gomez), yves.le-bissonnais@supagro.inra.fr (Y. Le Bissonnais)

\section{Abstract}

Soil aggregate stability is a key factor in soil resistance to water erosion, which is a threat to soils in a large part of northern Tunisia. The analysis of the spatial variability of soil aggregate stability provides both agronomic and environmentally useful information. However, extensive measurements of soil aggregate stability remain tedious and expensive.

This study explores two different approaches as alternative to measurements of soil aggregate stability. One approach estimated aggregate stability via laboratory measurements of soil elementary properties using multiple linear regressions known as pedotransfer functions. The second approach, which is methodologically innovating, was based on the geological pattern as a proxy for aggregate stability using regression-kriging analysis. A set of 113 soil samples from an $800 \mathrm{~km}^{2}$ agricultural region that included the Lebna watershed (Cap Bon, Tunisia) were collected from the soil surface layer $(0-10 \mathrm{~cm}$ depth). Samples were analyzed for elementary properties (i.e., soil texture, total carbon and nitrogen, iron, $\mathrm{CaCO}_{3}$, salinity, CEC and $\mathrm{pH}$ ) and for soil aggregate stability according to the normalized method (ISO/DIS 10930, 2012), which considers three indexes (MWD) calculated for three contrasted wetting conditions and disruptive energies.

Most soils in the study area were non-salted with an alkaline $\mathrm{pH}$ and relatively low organic carbon content. Of the soils, $35 \%$ were clay soils, and $55 \%$ had a balanced soil texture. The average of the three soil aggregate stability indexes (MWD mean) ranged from 0.38 to $2.80 \mathrm{~mm}$, and this property showed large variability from instable soils to very stable ones. Analysis of pedotransfer functions determined that the best predictor variables for soil aggregate stability were silt, organic matter and iron. Geostatistical analyses at the regional scale showed spatially structured soil aggregate stability (variograms with sills reaching a 5 $\mathrm{km}$ distance). Using geological information as ancillary data, the prediction of soil aggregate stability with regression-kriging was similar to that of pedotransfer functions. A regressionkriged map of soil aggregate stability associated with a map of prediction uncertainties was developed. The resulting maps and methods of this study can be useful in the development of management options that minimize water erosion risks in the studied area.

Keywords: Soil Aggregate Stability, Spatial Organization, Pedotransfer function, Regressionkriging analysis, Tunisia.

(C) 2017. This manuscript version is made available under the CC-BY-NC-ND 4.0

license http://creativecommons.org/licenses/by-nc-nd/4.0/ 


\section{Introduction}

Soil is a key component of the biosphere that determines the biogeochemical, hydrological and erosional cycles and delivers various essential ecosystems goods and services (Brevik et al., 2015; Keesstra et al., 2016). However, soils are often threat by several degradation factors among them soil erosion which is a clear indication of land degradation in the Mediterranean (García-Ruiz et al., 2013; García-Ruiz et al., 2017; Montanarella et al., 2016). Therefore preventing and combating soil erosion is a major environmental and economical challenge in this region where climate change is already perceptible (Den Biggelaar et al., 2004; Giorgi and Lionelle, 2008; Raclot et al., 2016). In Tunisia, the problem of soil erosion is more pronounced in the north part of the country in which the landscape is hilly and high-energy storms are frequent on bare soils during the autumn season (Jebari, 2009). Indeed, Kefi et al. (2012) show that $25 \%$ of the Tunisian septentrional area had an estimated annual soil loss rate that exceeded $30 \mathrm{t} \mathrm{ha}^{-1}$.

Aggregate stability is an intrinsic property of soils that is an empirical measurement (Le Bissonnais, 1996) of the ability of a soil aggregate to retain cohesion and not disintegrate under the action of water (Lal, 1991). Aggregate stability is particularly important to consider when issues are examined that relate to soil fertility and natural resources conservation (Cammeraat and Imeson, 1998; Amezketa, 1999; Bronick and Lal, 2005). Indeed, soil aggregate stability is used to evaluate the sensitivity of soil to crusting and erosion (Le Bissonnais, 1996; Cerdà, 2000; Barthès and Roose, 2002), the conditions for seed germination and rooting of crops (Lynch and Bragg, 1985) and the soil capacity to sequester organic carbon (Fenton et al., 2005). Therefore, the capacity to provide spatial predictions of this property is fundamental for landscape managers.

Research on soil aggregate stability is an essential requirement considering the importance of water erosion damages on site and off site (Keesstra et al., 2016; Montanarella et al., 2016). Indeed, soil aggregate stability is a definitive variable to understand soil erosion processes in agricultural and forest soils (Cerdà, 2000; GarcíaOrenes et al., 2012; Haregeweyn et al., 2013) since soil aggregate stability seemed to reflect better the actual vulnerability of topsoils to physical degradation (Stanchi et al., 2015). Moreover, soil aggregate stability studies serve as early warning signs of vulnerability and resilience of soils and can be very useful for evaluating the impacts of land use and erosion control management (Cammeraat and Imeson, 1998; Cerdà, 2000).

Soil aggregate stability is studied by examining the process of aggregate disintegration or the factors that stabilize aggregates. The primary mechanisms of aggregate breakdown are slaking, breakdown by differential swelling, mechanical breakdown by raindrop impact and physicochemical dispersion (Le Bissonnais, 1996). The relative importance of these mechanisms depends on the patterns of rain and the physical and chemical properties of soils. Stabilizing factors are primarily related to soil characteristics, which may be affected by agricultural practices. Aggregate stability generally increases with the content of clay and organic matter in soil, but a significant universal equation adapted to all types of soils and conditions has not been established (Le Bissonnais and Arrouays, 1997; Le Bissonnais et al., 2007; Chenu et al., 2011; Mamedov et al., 2016). Other parameters such as soil microorganisms and their activities and cations $\left(\mathrm{Ca}^{2+}\right.$ and $\mathrm{Fe}^{2+}$, among others) are also involved in soil aggregation and stabilization (Bragg and Lynch, 1985; Wuddivira and Camps-Roach, 2007).

The spatial distribution of soil structure and stability is a key element in water and soil functions, and therefore, the determination is relevant to understand and manage soil processes to sustain agro-ecosystems (Shukla et al., 2007; Van Es et al., 1999). Spatial variability is inherent due to geologic and pedologic soil forming factors, but a part of this variability may be induced by tillage and other management practices. However, information on the spatial variation of aggregate stability in a given region remains limited (Mohammadi and Motaghian, 2011) compared with that for other soil properties such as soil water retention parameters (Makitalo, 2002; Iqbal et al., 2005), texture (Jung et al., 2006; Ließ et 
al., 2012) and organic carbon content (Stutter et al., 2009; Hoffmann et al., 2014; Hu et al., 2014).

The first objective of this work was to determine the degree of spatial organization of levels of soil aggregate stability at the scale of an $800 \mathrm{~km}^{2}$ agricultural region. The second objective was to assess two different approaches to predict soil aggregate stability: i) one approach used pedotransfer functions consisting of multiple linear regressions based on conventional soil properties, and ii) the other approach was regression-kriging based on ancillary spatial data, which in this study, were the geological substrate data. The second approach tested here is, to our knowledge, applied for the first time to soil aggregate stability studies. Assessment of the two approaches was performed using a leave-one-out crossvalidation (LOOCV) technique applied to a sample collection of 113 soil samples from an agricultural region located on the Cap Bon Peninsula in the northeast of Tunisia.

\section{Materials and methods}

\subsection{Site description and sampling}

Soil samples were collected in a hilly, rural area covering approximately $40 \times 20 \mathrm{~km}$ between the southeastern flank of the Djebel Abderrahmane anticline and the east coast of the Cap Bon Peninsula in northeast Tunisia $\left(36^{\circ} 24^{\prime}-53^{\prime} \mathrm{N}, 10^{\circ} 20^{\prime}-58^{\prime} \mathrm{E}\right.$; Fig. 1a). The elevation of the study area ranges from $250 \mathrm{~m}$ at the foot slope of the djebel (west of the study area) to $20 \mathrm{~m}$ near the coast (east of the study area). The area includes most of the Lebna watershed, which drains into the Lebna reservoir. The climate is at the boundary between Mediterranean sub-humid inferior and Mediterranean semi-arid superior with an average annual rainfall ranging from $650 \mathrm{~mm}$ in the west to $450 \mathrm{~mm}$ in the east of the study area, a mean annual temperature of approximately $18^{\circ} \mathrm{C}$ and an interannual potential evapotranspiration of approximately $1200 \mathrm{~mm}$.

The primary soil types are regosols and eutric regosols predominantly associated with sandstone outcrops, calcisols associated with sandy Pliocene deposits, and vertisols predominantly formed on marl outcrops and in lowlands.

Except for some nearby sandstone outcrop areas and a small endorheic salt zone (sebkhas), which are covered by sparse natural vegetation and used for grazing, most of the area is cultivated with rain fed cereals, legumes and olive trees. Irrigated horticulture conducted by pumping groundwater or supplied by water dams covers small areas located near the coastal plain at the far east of the study site.

Soil samples were collected from the soil surface layer $(0-10 \mathrm{~cm})$ of 113 plots in October 2009. Each sample was composed of five subsamples collected at random locations within a 10x10 m square. The coordinates of each sample location were recorded using a Garmin GPS instrument ensuring an accuracy of $5 \mathrm{~m}$ for geolocalization. In the laboratory, soil samples were air-dried and divided into two aliquots. The first aliquot was sieved through a $2 \mathrm{~mm}$ mesh and was used for elementary soil analyses, whereas from the second aliquot, only 3-5 $\mathrm{mm}$ aggregates were retained to assess soil aggregate stability.

\subsection{Soil properties measured}

Ten physicochemical properties of the soils were measured in triplicate on the $2 \mathrm{~mm}$ sieved samples using classical physico-chemical soil analysis (Baize and Jabiol, 1995): clay, silt, and sand content measured according to the pipette method with Nahexametaphosphate NF $X$ 31-107; calcium carbonate $\left(\mathrm{CaCO}_{3}\right)$ content determined by volumetric method according to the NF ISO 10693; free iron (Fe) content determined according to the Mehra-Jackson method (ICP-AES); organic carbon (OC) content determined by dry combustion with an elemental analyser according to the NF ISO 10694; organic nitrogen $(\mathrm{N})$ content measured by Kjeldahl method according to the NF ISO 11261; cation exchange capacity (CEC) determined by Metson Method according to the NF $X$ 31130; electrical conductivity (EC) and $\mathrm{pH}\left(\mathrm{H}_{2} \mathrm{O}\right)$ were carried out on a soil : water suspension (1:5) according to the NF ISO 11265 and to the NF ISO 10390, respectively. 
Aggregate stability was determined according to the normalized method (ISO/DIS 10930, 2012), based on Le Bissonnais (1996). This method combines three disruptive tests that use different wetting conditions and energies: fast wetting, slow wetting and mechanical breakdown. These tests were performed in triplicate on the $3-5 \mathrm{~mm}$ aggregates that were recovered by double-sieving of soil samples between 3 and $5 \mathrm{~mm}$ sieves.

For the fast wetting test, $5 \mathrm{~g}$ of 3-5 mm calibrated aggregates was rapidly immersed in $50 \mathrm{~mL}$ of deionized water for $10 \mathrm{~min}$. For the slow wetting test, a similar amount of aggregates were capillary rewetted with water on a tension table at a potential of $-0.3 \mathrm{kPa}$ for $30 \mathrm{~min}$. For the mechanical breakdown test, aggregates were hand-agitated in $200 \mathrm{~mL}$ of deionized water after pre-wetting in ethanol for $30 \mathrm{~min}$.

After each test, the residual aggregates were collected, dried at $105^{\circ} \mathrm{C}$ and gently drysieved using a column of six sieves ranging from 2 to $0.05 \mathrm{~mm}$. The mass proportion of each fraction size of stable aggregates was calculated, and the results were expressed as a mean weight diameter index (MWD) corresponding to the sum of the mass fraction remaining on each sieve multiplied by the mean inter-sieve size. MWD was calculated for each treatment $\left(M W D_{\mathrm{FW}}, M W D_{\mathrm{MB}}\right.$ and $M W D_{\mathrm{sW}}$, respectively, for fast wetting, mechanical breakdown and slow wetting). The average of these three indexes was also calculated ( $\left.M W D_{\text {mean }}\right)$. MWD values ranged between 0.025 and $3500 \mathrm{~mm}$, with larger MWD values representing greater aggregate stability. Five classes of aggregate stability are defined by Le Bissonnais (1996) based on the MWD: very instable soils (MWD $<0.4 \mathrm{~mm})$, instable soils $(0.4 \mathrm{~mm}<\mathrm{MWD}<0.8$ $\mathrm{mm})$, moderately stable soils $(0.8 \mathrm{~mm}<\mathrm{MWD}<1.3 \mathrm{~mm})$, stable soils $(1.3 \mathrm{~mm}<\mathrm{MWD}<2.0 \mathrm{~mm})$ and very stable soils (MWD>2.0 mm).

\subsection{Ancillary data}

Ancillary data consisted of geological substrate information derived from the collection of standard 1/50000 geological maps of Tunisia that are available for most of the country. The dominant geological material in the study site (Fig. 1b, geological unit 2) is composed of marls intercalated with Serravalian-Tortonian sandstone beds (Bensalem, 1989). Toward the coast in the east, soft-sandy layers and thin layers of hard calcareous sandstone with Pliocene marine origin alternate (Fig. 1b, geological unit 1), which have some parts still encrusted with limestone explaining the presence of a sub-horizontal plateau at an altitude of approximately $100 \mathrm{~m}$ primarily in the northeast of the area (Fig. 1b, geological unit 3). The other geological units of the geological maps refer to recent and old terrestrial deposits near the wadis (Fig. 1b, geological unit 5) and recent coastal deposits (Fig. 1b, geological unit 4).

\subsection{MWD spatial structure estimation}

Assuming a second-order stationary spatial variable, the magnitude and organization of spatial variability of MWD variables were first determined using anisotropic variogram (semi-variance) analysis as proposed by Mohammadi and Motaghian (2011). The significance of organization (i.e., spatial correlation) in MWD was tested by comparing the experimental semi-variogram with the semi-variogram envelope based on permutations of the data values across the locations (number of simulations $N_{\text {sim }}=100$ ), simulating a nonspatially correlated variable (Mantel test). In this empirical test, a spatial correlation was considered significant at a 95\% level for the lower distance, which was with the experimental semi-variogram below the envelope.

\subsection{MWD prediction using pedotransfer functions}

Multiple linear regression models were used to build pedotransfer functions, which established relationships between aggregate stability indexes and elementary soil properties. The choice of the soil properties used in pedotransfer functions was performed according to the stepwise methodology using the Akaike Information Criterion (AIC) to evaluate models (Akaike, 1973). The AIC evaluates the trade-off between the goodness of fit of the model and the complexity of the model, and therefore, determines the number of parameters (predictors) in the model. The preferred model has the minimum AIC value.

(C) 2017. This manuscript version is made available under the CC-BY-NC-ND 4.0

license http://creativecommons.org/licenses/by-nc-nd/4.0/ 


\subsection{MWD prediction using regression-kriging approach based on geological substrate information}

According to the geostatistical spatial prediction modeling framework proposed by Hengl et al. (2004), regression-kriging was used for the spatial prediction of MWD. In the first regression step, geological units derived from $1 / 50000$ geological maps were tested as a proxy to predict the MWD variability. An MWD prediction for each of the geological units was first derived from an ANOVA analysis. In the second step, a second-order stationary geostatistical analysis was conducted on the residuals, i.e., the difference between the measured MWD and the predicted value of MWD from the fitted ANOVA model, to explore whether all the spatial organization of MWD was encapsulated in the geological class units. To ensure proper residual variogram modeling, each residual variable was checked for normality and anisotropy. In the same way, we also checked that a similar variogram model whatever the geological class unit (second-order stationary) could be assumed using the following specific simulation test. In this test, an envelope of an empirical variogram was built from simulated residuals values (the exact LU decomposition method) on sample locations from the isotropic variogram modeling resulting from the 113 residuals initial values. Similar to the previous simulation test, a non-significant difference in a variogram was assumed for one geological class unit when the actual empirical variogram points built from residuals in that geological class unit were within the 95\% simulation envelope. By comparing the experimental semi-variograms with semi-variogram envelopes based on permutations $\left(\mathrm{N}_{\mathrm{sim}}=\right.$ 100), the significance of spatial structure (empirical variograms) was also tested. After this step of spatial structure exploration, admissible models were fitted to variograms of residuals by ordinary least squares minimization. As a final step, a predicted grid and contour map of each MWD (i.e., $M W D_{F W}, M W D_{M B}, M W D_{s w}$ and $M W D_{\text {mean }}$ ) were created by combining the results of the linear ANOVA predictions and the ordinary kriging of the residuals.

\subsection{Performance assessment of MWD prediction}

For the two methods tested, a similar leave-one-out cross-validation (LOOCV) process was applied to validate MWD predictions. Prediction performance was assessed using the statistical criteria of the root mean squared error (RMSE), the normalized root mean squared error (CVRMSE) and the coefficient of efficiency (CE, Nash and Sutcliffe, 1970), which were calculated using the following formulas:

$$
\begin{aligned}
& R M S E=\sqrt{\frac{\sum_{1}^{n}\left(\text { Predicted }_{i}-\text { Observed }_{i}\right)^{2}}{n}} \\
& C V R M S E=\frac{R M S E}{\bar{O}} \\
& C E=1-\frac{\sum_{1}^{n}\left(\text { Observed }_{i}-\text { Predicted }_{i}\right)^{2}}{\sum_{1}^{n}\left(\text { Observed }_{i}-\bar{O}\right)^{2}}
\end{aligned}
$$

where $n$ is the number of observations (113, in this study) and $\bar{O}$ is the overall mean of observed values.

Small values of RMSE and CVRMSE indicated good performance of the model. The $C E$ is a measure of the deviation between model output and the observed values relative to the scattering of the measured values. The value of CE will be 1 when simulated values match the observed values perfectly. We also analyzed the calibration regression coefficients established using the entire data set $(n=113)$ as an additional criteria of MWD prediction performance related to pedotransfer functions.

All statistical analyses were conducted using the $\mathrm{R}$ statistical software package with the geoR and gstat modules (R Core Team, 2013).

(c) 2017. This manuscript version is made available under the CC-BY-NC-ND 4.0

license http://creativecommons.org/licenses/by-nc-nd/4.0/ 


\section{Results}

\subsection{Soil elementary properties}

Soil elementary properties showed high variability over the study area (Table 1). Most of the soils were non-salted with an alkaline $\mathrm{pH}$ and relatively low organic carbon content (Table 1). Sampled soils were clustered into three textural classes: clay soils (35\%), soils with balanced texture (55\%) and sandy soils (10\%) (Fig. 2). Moreover, the clay and sand contents were significantly correlated with CEC, Fe content and pH (Table 2).

\subsection{Soil aggregate stability}

The three aggregate stability indexes also showed high variability over the study area (Fig. 3), and four of the five classes of stability defined by Le Bissonnais (1996) were represented. The $\mathrm{MWD}_{\mathrm{FW}}$ values were lower than those of the other two tests, which is consistent with literature reports that rapid penetration of water inside the soil aggregate induces more slaking because of the effect of the created pressure. MWD $\mathrm{Fw}_{\mathrm{F}}$ values varied from 0.35 to $2.82 \mathrm{~mm}$ with an average of $0.90 \pm 0.46 \mathrm{~mm}$.

The MWD $\mathrm{MW}_{\mathrm{sw}}$ values ranged from 0.51 to $3.06 \mathrm{~mm}$ with an average of $1.80 \pm 0.64 \mathrm{~mm}$. In this procedure, soil aggregates were slowly wetted, which prevents slaking, and therefore, the $M W D_{\text {sw }}$ values were higher than those of the MWD $D_{\text {FW. }}$

The $M W D_{\text {мв }}$ values obtained with the mechanical breakdown test were larger than those of $\mathrm{MWD}_{\mathrm{FW}}$; they varied from 0.38 to $2.80 \mathrm{~mm}$ with a mean of $1.24 \pm 0.68 \mathrm{~mm}$. In the mechanical breakdown test, slaking does not occur because aggregate porosity is saturated with ethanol, which decreases the surface tension and contact angle, favoring water penetration. Therefore, in this test, the abrasion of the aggregates against one another during the mechanical stirring is the primary cause of aggregate breakdown.

The calculation of the average (MWD mean $)$ of the three tests $\left(M W D_{\mathrm{Fw}}, M W D_{\mathrm{sw}}\right.$ and $M W D_{\mathrm{MB}}$ ) provided an overall view of aggregate stability at different conditions of soil wetness. The $M W D_{\text {mean }}$ values showed that soil aggregate stability was highly variable in the study area. The $M W D_{\text {mean }}$ values ranges from 0.46 to $2.52 \mathrm{~mm}$ with an average of $1.31 \pm 0.50 \mathrm{~mm}$. Thus, most $(69 \%)$ of the study area soils were moderately stable to stable, and no soil was classified as very instable (MWD mean $<0.4 \mathrm{~mm}$ ).

\section{Factors and MWD prediction performance related to pedotransfer functions}

The Pearson correlations were not significant between the soil aggregate stability indexes and four of the measured elementary soil properties (OC, N, $\mathrm{CaCO}_{3}$ and $\mathrm{EC}$; Table 2). For the other six elementary soil properties (clay, silt, sand, $\mathrm{CEC}, \mathrm{pH}$ and $\mathrm{Fe}$ ), significant, simple linear relationships were detected with the soil aggregate stability indexes.

Multiple linear models were used to build pedotransfer functions from the physicochemical analysis to estimate each soil aggregate stability index. Sand content and CEC were excluded from the list of factors entering the multiple linear models because high levels of multicollinearity were observed between clay, sand and CEC (Table 2). Similarly, N was discarded because of collinearity with OC.

The pedotransfer functions for each soil aggregate stability index were as follow:

[1] $\quad \mathrm{MWD}_{\mathrm{FW}}=0.5227+0.0015$ Clay $-0.01210 \mathrm{C}(\mathrm{r}=0.624, \mathrm{AIC}=-226)$;

[2] $\mathrm{MWD}_{\mathrm{sw}}=0.9535+0.0036$ Silt-0.02720C+0.0011CaCO $\mathrm{Ca}_{3}+0.4300$ Iron $\quad(r=0.601$, $\mathrm{AIC}=-140)$;

[3] $\quad \mathrm{MWD}_{\mathrm{MB}}=0.2620+0.0052$ Silt-0.03580C+0.4784Iron $(r=0.731, \mathrm{AIC}=-167)$;

[4] $\mathrm{MWD}_{\text {mean }}=0.5502+0.0031$ Silt-0.02140C+0.4460Iron $(r=0.736, \mathrm{AIC}=-235)$.

According to $p$-values, silt, organic carbon and iron were significant $(p<0.01)$ for modeling the $\mathrm{MWD}_{\text {mean }}, \mathrm{MWD}_{\mathrm{MB}}$ and $M \mathrm{MWD}_{\mathrm{sw}}$. Clay was only significant for the $M \mathrm{MWD}_{\mathrm{FW}}$ 
pedotransfer function $(\mathrm{p}<0.01)$. Last, $\mathrm{pH}$ and $\mathrm{EC}$ were also discarded because they had no significant weight in the building of pedotransfer functions for any of the four soil aggregate stability indexes.

When the entire data set was used in the calibration process $(n=113)$, the regression coefficient ranged from 0.61 to 0.74 ; thus, the prediction performances of the pedotransfer functions were intermediate but significant. The best goodness of fit was obtained for $M W D_{\text {mean }}$ and $M W D_{\text {MB. }}$. The pedotransfer prediction performance was also evaluated using an LOOCV technique that confirmed a moderate to high prediction performance (Table 3) with an RMSE ranging from 0.37 to 0.55 , a CVRMSE from 0.28 to 0.43 and CE from 0.36 to 0.54 (Fig. 4).

\subsection{Spatial organization of MWD}

Experimental semivariograms and envelopes were obtained by permutation from the different measured MWD indexes (Fig. 5). The results demonstrated a significant spatial correlation of the different soil aggregate stability indexes over a distance of approximately 5 $\mathrm{km}$. This spatial correlation was higher for $M W D_{\mathrm{FW}}$ and $M W D_{\text {mean }}$ than that for $M W D_{\mathrm{sw}}$ and $M W D_{M B}$.

\subsection{Spatial prediction of MWD using the regression-kriging approach}

The results of the analysis of variance conducted between MWD values and the five units of the geological map at 1/50000 showed that significant MWD differences between some geological units were detected regardless of the MWD test. Therefore, a large part of the MWD spatial organization was encapsulated in the geological map. However, empirical variograms on the residuals of this ANOVA model (Fig. 6) showed that a spatial organization remained in the residuals. Therefore, the geological information did not encapsulate the entire spatial variability of MWD, which indicated that an additional kriging technique on the residuals might improve the prediction. The additional kriging was performed using the regression-kriging approach, and a spherical model was selected as the variogram function according to its fitting capacities on the overall behavior of the experimental variogram.

As determined for pedotransfer functions, prediction performances of the regressionkriging approach were evaluated using the LOOCV technique. Based on the values of RMSE, CVRMSE and CE (Table 3), the prediction performances using regression-kriging models were as good as those obtained with pedotransfer functions.

Experimental variograms frequently show a discontinuity at the origin known as the nugget variance, which represents the random variability at the sampling scale and reflects the variability at distances closer than the smallest sampling distance, measurement errors or errors in location (Webster and Oliver, 2007). In our study, the nugget values were from 0.06 to 0.19 , which suggested that a smallest sampling distance should be tested to capture the local variation in MWD values. Sill values were from 0.13 to 0.33 and range values from 4000 to 8000 meters.

As shown in Fig. 7a, globally, the spatial variability of predicted MWD values was very similar regardless of the MWD considered, with higher values in the north and the eastern part of the study area and lower MWD values in the western part as approaching the coast. In Fig. 7b, the standard deviation is estimated on the predicted map for each MWD, which should be of interest for decision makers.

\section{Discussion}

\subsection{Level and variability of MWD in the study area}

The soil aggregate stability values for agricultural fields on the Cap Bon Peninsula were similar to those noted by Bouajila and Gallali (2008) for many cultivated soils of northern Tunisia. However, the levels of aggregate stability observed in this study were lower than those observed in Mediterranean fallow or scrubland soils (Blavet et al., 2009). The three aggregate stability tests used in this study simulate different wetting conditions and energies that can occur in the field, with the following effects on aggregate stability (Le 
Bissonnais, 1996): (i) slaking caused by the compression of air entrapped inside aggregates during wetting, which is dependent on the rate of wetting, (ii) mechanical breakdown, which is dependent on the energy applied from raindrops, and (iii) physicochemical dispersion, which occurs in soils with high clay content and exchangeable sodium. In the fast and slow wetting tests, the dominant breakdown mechanism is slaking at different intensities according to the rate of aggregate wetting. In the fast wetting test, which corresponds to a rain of strong intensity (>30 $\mathrm{mm} \mathrm{h}^{-1}$ ) (Legout et al., 2005), more intense slaking is observed because of the larger compression of entrapped air inside the aggregates when suddenly immersed in water. In the mechanical breakdown test, no slaking occurs during because aggregate porosity is saturated with ethanol, which decreases surface tension and the contact angle, favoring water penetration. The mechanical breakdown test simulates the impact of raindrops on wet aggregates detaching soil particles. The fast wetting test was the closest approximation of the erosion-prone conditions in the Lebna watershed, because the test assessed the response of bare and dry soils to intense wetting such as occurs with rainfall storms in autumn.

At the scale of our study area, the large variability within an area is important to understand because soil aggregate stability is often used as a proxy for soil erodibility (Le Bissonnais 1996; Barthes and Roose, 2002). Such variation in levels of soil aggregate stability across a region is observed in other studies (Chenu et al., 2000; Odeh and Onus, 2008; Cañasveras et al., 2010; Mohammadi and Motaghian, 2011), and this variability is generally attributed to soil characteristics (Boix-Fayos et al., 2001), topography (Canton et al., 2009), climate (Algayer, 2012) and to the land use/management (Bird et al., 2002; Motaghian and Mohammadi, 2011). The wide range of measured values of aggregate stability observed in our study could be related in particular to the wide range in soil texture as shown in fig. 2. This textural variability was clearly related to the geological characteristics, which explained much of the MWD spatial organization. However, most of the tested samples corresponded to a relatively low level of aggregate stability: between 0.5 and 1.1 $\mathrm{mm}$ for more than $50 \%$ of the samples with the fast wetting test, which is the most relevant to characterize the aggregate resistance to breakdown in the Mediterranean area because of the high frequency of high intensity rainfall.

\subsection{Factors involved in pedotransfer functions}

We examined the relationships between aggregate stability and elementary soil properties (i.e., organic matter content, texture, and carbonates, among the others) because these variables are measured routinely and statistically significant relations with aggregate stability are reported in the literature (Wischmeier and Mannering, 1969; Amezketa, 1999; Zhang and Horn, 2001). Therefore, these elementary soil properties have been tested as potential factors to explain the spatial distribution of aggregate stability. Moreover, several studies show that the stability of aggregates is usually due to amorphous materials in the soil, primarily clays and organic matter (Chenu et al., 2000; Le Bissonnais et al., 2007; Chenu et al., 2011).

Soil organic carbon was not a leading indicator of aggregate stability in our study area (Table 2), which could be partly explained by the low range of organic carbon content in most of the sampled soils (98\% of soil samples were in the range $0.2-2 \%$ ). Additionally, the aggregating role of organic matter can be offset by the effect of dissolved organic matter in low organic matter soils (Goldberg et al., 1990). Simple linear correlations showed no significant relationship between MWD and soil carbonate content, as also observed by Bird et al. (2002). The absence of a correlation between soil carbonates and aggregation was most likely due to more efficient aggregating factors such as clays and metal oxides (Le Bissonnais and Singer, 1993). However, significant correlations were observed between soil aggregate stability indexes and other soil properties (i.e., particle size, CEC, Fe and pH) in this study, which are the types of relationships observed in other studies (Pons and Gerbaud, 2005; Cañasveras et al., 2010; Algayer, 2012). However, no single soil property had a strong significant relationship with any of the soil aggregate stability indexes (Table 2). Finally, for

(C) 2017. This manuscript version is made available under the CC-BY-NC-ND 4.0

license http://creativecommons.org/licenses/by-nc-nd/4.0/ 
the proposed pedotransfer functions, the prediction performance was intermediate but significant ( $r$ values ranging from 0.61 to 0.74 ; RMSE from 0.37 to 0.55 ; CVRMSE from 0.28 to 0.43 ; and CE from 0.36 to 0.54 ). Silt and iron were the most significant properties in building regressions and therefore determined a portion of the soil aggregate stability.

However, elementary soil properties did not explain the entire observed variability in stability of soil aggregates. Based on a comparison of results derived from pedotransfer functions in other contexts (Le Bissonnais et al., 2007; Chenu et al., 2011), the soil properties involved in pedotransfer functions are likely site-specific, and therefore, the levels of soil aggregate stability cannot be predicted satisfactorily by a universal pedotransfer function. Interactions with other variables most likely explain this result, with these variables related to the soil as components of organic matter quality and microbial activity; in addition to the effects of climate on soil moisture and wetting-drying cycles and those of land use and farmer practices.

\subsection{Importance of geological information for MWD prediction in Mediterranean area}

In the study area, the pattern of the geological map at 1/50000 explained much of the spatial organization of topsoil aggregate stability. Therefore, the primary driver of topsoil aggregate stability in the study area was the nature of the substrates and surface deposits, which could be used as a first order proxy for MWD. This conclusion was consistent with results from the pedotransfer approach because most factors involved in pedotransfer functions, i.e., texture, iron content and organic carbon content, directly depended on information included in the geological map. In our study area, land use and management primarily consist of rain fed cereals and leguminous crops managed in a traditional tillage management system with very low organic inputs. The relative homogeneity in farming management might explain that the low effect of this factor on MWD values.

However, the geological substrate did not represent all the spatial organization of soil aggregate stability in the studied area. Therefore, we applied a regression-kriging prediction model that developed a soil aggregate stability map at a regional scale, in addition to predicting uncertainties that included the effects of others variables that were not explicitly integrated into the spatial organization model.

\section{Conclusions}

The spatial organization of soil aggregate stability was investigated in an $800 \mathrm{~km}^{2}$ agricultural region in Cap Bon, North Tunisia. Low to moderate levels of aggregate stability dominated the study site. Two different approaches for MWD prediction in the cultivated area were tested and compared. The first one is based on classical pedotransfer functions whereas the second one consists in an innovative regression-kriging approach, which aims to rapidly map MWD on large area by using existing ancillary data. In our case, the regression-kriging approach was based on existing geological information as ancillary data and provided prediction performances for the three MWD treatments that were as good as those using the pedotransfer functions. However, compared with pedotransfer functions, which also provided an acceptable level of prediction, the regression-kriging approach has advantages: the method is easier and cheaper to map MWD because laboratory soil analyses are not required, and MWD map prediction can be established with related uncertainties that can be very useful for management considerations. For example, the approach is used to evaluate interrill erodibility parameters as a direct input in distributed erosion models (e.g., Gumiere et al., 2010). Further investigations in similar conditions are required to verify that the geological information remains the first order factor to map soil aggregate stability in the Maghreb agricultural region dominated by rain fed crops. It is also necessary to test whether MWD prediction performance using the regression-kriging approach can be improved by including additional ancillary data such as topography, land use, land management, and biological activity in the first regression step of the method. 


\section{Acknowledgments:}

The project 'DIGISOL-HYMED' (ANR-08-BLAN-0284-01) from the French National Research Agency (ANR) and the ARIMNet2 'MASCC' project financially supported this work. The authors are indebted to Yves Blanca (IRD-UMR LISAH Montpellier), Zakia Jenhaoui (IRD-UMR LISAH Tunis) for the soil sampling in 2009 and to Hedi Hamrouni (DG/ACTA Sol, Tunis) for providing significant support to this study. Finally, we are indebted to Emna Boukari and Amira Askri for the soil aggregate stability measurements and to the LMI Naila members for scientific facilitation.

\section{REFERENCES}

Akaike, H., 1973. Information theory as an extension of the maximum likelihood principle, in Petrov, N., and Csaki, F., (Eds.), Second International Symposium on Information Theory. Akademiai Kiado, Budapest, pp. 267-281.

Algayer, B., 2012. Variabilité à court terme de la stabilité structurale des sols et processus physico-chimiques associés. PhD thesis, Orléans Univ, France.

Amezketa, E., 1999. Soil aggregate stability: A review. Journal of Sustainable Agriculture. 14, 83-151.

Barthès, B., Roose, E., 2002. Aggregate stability as an indicator of soil susceptibility to runoff and erosion; validation at several levels. Catena. 47, 133-149.

Bensalem, H., 1989. Carte géologique de la Tunisie au 1/50000. Département de la Géologie de l'office National des mines, feuilles 15, 16, 22 et 23.

Bird, S.B., Herrick, J.E., Wander, M.M., Wright, S.F., 2002. Spatial heterogeneity of aggregate stability and soil carbon in semi-arid rangeland. Environmental Pollution. $116,445-455$.

Blavet, D., De Noni, G., Le Bissonnais, Y., Leonard, M., Maillo, L., Laurent, J.Y., Asseline, J., Leprun, J.C., Arshad, M.A., Roose, E., 2009. Effect of land use and management on the early stages of soil water erosion in French Mediterranean vineyards. Soil Till. Res. 106, 124-136.

Boix-Fayos, C., Calvo-Cases, A., Imeson, A.C., Soriano-Soto, M.D., 2001. Influence of soil properties on the aggregation of some Mediterranean soils and the use of aggregate size and stability as land degradation indicators. Catena. 44, 47-67.

Bouajila, A., Gallali, T., 2008. Soil organic carbon fractions and aggregate stability in carbonated and no carbonated soils in Tunisia. Journal of Agronomy. 7, 127-137.

Brevik, E.C., Cerdà, A., Mataix-Solera, J., Pereg, L., Quinton, J.N., Six, J., Van Oost, K., 2015. The interdisciplinary nature of soil. SOIL. 1, 117-129.

Bronick, C.J., Lal, R., 2005. Soil structure and management: a review. Geoderma. 124, 3-22.

Cammeraat, L.H., Imeson, A.C., 1998. Deriving indicators of soil degradation from soil aggregation studies in SE Spain and southern France. Geomorphology. 23, 307-321.

Cañasveras, J.C., Barrón, V., del Campillo, M.C., Torrent, J., Gómez, J.A., 2010. Estimation of aggregate stability indices in Mediterranean soils by diffuse reflectance spectroscopy. Geoderma. 158, 78-84.

Cantón, Y., Solé-Benet, A., Asensio, C., Chamizo, S., Puigdefábregas, J., 2009. Aggregate stability in range sandy loam soils Relationships with runoff and erosion. Catena. 77, 192-199.

Cerdà, A., 2000. Aggregate stability against water forces under different climates on agriculture land and scrubland in southern Bolivia. Soil Till. Res. 57, 159-166.

Chenu, C., Le Bissonnais, Y., Arrouays, D., 2000. Organic matter influence on clay wettability and soil aggregate stability. Soil Sci. Soc. Am. J. 64, 1479-1486.

Chenu, C., Abiven, S., Annabi, M., Barray, S., Bertrand, M., Bureau, F., Cosentino, D., Darboux, F., Duval, O., Fourrié, L., Francou, C., Houot, S., Jolivet, C., Laval, K., Le Bissonnais, Y., Lemée, L., Menasseri, S., Pétraud, J.P., Verbeque, B., 2011. Mise au point d'outils de prévision de l'évolution de la stabilité de la structure de sols sous l'effet de la gestion organique des sols. Etudes et Gestion des Sols. 18, 137-151.

(C) 2017. This manuscript version is made available under the CC-BY-NC-ND 4.0

license http://creativecommons.org/licenses/by-nc-nd/4.0/ 
Den Biggelaar, C., Lal, R., Wiebe K., Breneman, V., 2004. The global impact of soil erosion on productivity. 1: Absolute and relative erosion-induced yield losses. Advances in Agronomy. 81, 1-48.

García-Orenes, F., Roldán, A., Mataix-Solera, J., Cerdà, A., Campoy, M., Arcenegui, V., Caravaca, F., 2012. Soil structural stability and erosion rates influenced by agricultural management practices in a semi-arid Mediterranean agro-ecosystem. Soil Use Manag. 28, 571-579.

García-Ruiz, J.M., Nadal-Romero, E., Lana-Renault, N., Beguería, S., 2013. Erosion in Mediterranean landscapes: changes and future challenges. Geomorphology. 198, 2036.

García-Ruiz, J.M., Beguería, S., Lana-Renault, N., Nadal-Romero, E., 2017. Ongoing and Emerging Questions in Water Erosion Studies. Land Degrad. Dev. 28, 5-21.

Giorgi, F., Lionelle, P., 2008. Climate change projections for the Mediterranean region. Global and Planetary Change. 63, 90-104.

Goldberg, S., Kapoor, B.S., Rhoades, J.D., 1990. Effect of aluminum and iron oxides and organic matter on flocculation and dispersion of arid zone soils. Soil Sci. 150, 588-593.

Gumiere, S.J., Raclot, D., Cheviron, B., Davy, G., Louchart, X., Fabre, J.C., Moussa, R., Le Bissonnais, Y., 2011. MHYDAS-Erosion a distributed single-storm water erosion model for agricultural catchment. Hydrological Processes. 25, 1717-1728.

Haregeweyn, N., Poesen, J., Verstraeten, G., Govers, G., de Vente, J., Nyssen, J., Deckers, J., Moeyersons, J., 2013. Assessing the performance of a spatially distributed soil erosion and sediment delivery model (WATEM/SEDEM) in Northern Ethiopia. Land Degrad. Dev. 24, 188-204.

Hengl, T., Heuvelink, G.B.M., Stein, A., 2004. A generic framework for spatial prediction of soil variables based on regression-kriging. Geoderma. 120, 75-93.

ISO/DIS 10930., 2012. Soil quality - Measurement of the stability of soil aggregates subjected to the action of water. International Organization for Standardization, Geneva, Switzerland.

Jebari, S., 2009. Water Erosion Modeling using Fractal Rainfall Disaggregation - A Study in Semiarid Tunisia. PhD Thesis, Lund Univ, Sweden.

Keesstra, S.D., Bouma, J., Wallinga, J., Tittonell, P., Smith, P., Cerdà, A., Montanarella, L., Quinton, J.N., Pachepsky, Y., van der Putten, W.H., Bardgett, R.D., Moolenaar, S., Mol, G., Jansen, B., and Fresco, L.O., 2016. The significance of soils and soil science towards realization of the United Nations Sustainable Development Goals, SOIL. 2, 111-128.

Kefi, M., Yoshino, K., Setiawan, Y., 2012. Assessment and mapping of soil erosion risk by water in Tunisia using time series MODIS data. Paddy and Water Environment. 10, 5973.

Lal, R., 1991. Soil structure and sustainability. Journal of sustainable agriculture. 1, 67-92.

Le Bissonnais, Y., Singer, M.J., 1993. Seal formation, runoff, and interrill erosion from seventeen California soils. Soil Science Society of America Journal. 57, 224-229.

Le Bissonnais, Y., 1996. Aggregate stability and assessment of soil crustability and erodibility: I. Theory and methodology. Eur. J. Soil. Sci. 47, 425-431.

Le Bissonnais, Y., Arrouays, D., 1997. Aggregate stability and assessment of soil crustability and erodibility. II. Application to humic loamy soils with various organic carbon contents. Eur. J. Soil. Sci. 48, 39-48.

Le Bissonnais, Y., Blavet, D., De Noni, G., Laurent, J.Y., Asseline, J., Chenu, C., 2007. Erodibility of Mediterranean vineyard soils: relevant aggregate stability methods and significant soil variables. Eur. J. Soil. Sci. 58, 188-195.

Legout, C., Leguédois, S., Le Bissonnais, Y., 2005. Aggregate breakdown dynamics under rainfall compared with aggregate stability measurements. Eur. J. Soil Sci. 56, 225-237.

Lynch, J.M., Bragg, E., 1985. Microorganisms and soil aggregate stability. Advances in Soil Science. 2, 133-171.

Mamedov, A. I., Huang, C., Aliev, F.A., Levy, G.J., 2016. Aggregate Stability and Water

(C) 2017. This manuscript version is made available under the CC-BY-NC-ND 4.0

license http://creativecommons.org/licenses/by-nc-nd/4.0/ 
Retention Near Saturation Characteristics as Affected by Soil Texture, Aggregate Size and Polyacrylamide Application. Land Degrad. Dev. DOI: 10.1002/ldr.2509

Mohammadi, J., Motaghian, MH., 2011. Spatial Prediction of Soil Aggregate Stability and Aggregate-Associated Organic Carbon Content at the Catchment Scale Using Geostatistical Techniques. Pedosphere. 21, 389-399.

Montanarella, L., Pennock D.J., McKenzie, N., Badraoui, M., Chude, V., Baptista, I., Mamo, T., Yemefack, M., Aulakh, M.S., Yagi, K., Hong, S.Y., Vijarnsorn, P., Zhang, G., Arrouays, D., Black, H., Krasilnikov, P., Sobocká, J., Alegre, J., Henriquez, C.R., Mendonça-Santos, M.L., Taboada, M., Espinosa-Victoria, D., AlShankiti, A., AlaviPanah, S.K., Elsheikh, E.A.M., Hempel, J., Arbestain, M.C., Nachtergaele, F., Vargas, R., 2016. World's soils are under threat. SOIL. 2, 79-82.

Nash, J.E., Sutcliffe, J.V., 1970. River flow forecasting through conceptual models 1: a discussion of principles. Journal of Hydrology. 10, 282-290.

Odeh, I.O.A., Onus, A., 2008. Spatial Analysis of Soil Salinity and Soil Structural Stability in a Semiarid Region of New South Wales, Australia. Environmental Management. 42, 265278.

Pons, Y., Gerbaud, A., 2005. Classification agronomique des sols de marais à partir de la relation entre sodicité et stabilité structurale. Étude et Gestion des Sols. 12, 229-244.

R Core Team., 2013. R: A language and environment for statistical computing. R Foundation for Statistical Computing, Vienna, Austria.

Raclot, D., Le Bissonnais, Y., Annabi, M., Sabir M., 2016. Challenges for mitigating Mediterranean soil erosion under global change, In Thiébault, S., and Moatti, J.P., (Eds.). The Mediterranean region under climate change: a scientific update. Marseille, AllEnvi, pp. 311-318.

Shukla, M.K., Lal, R., Van Leeuwen, D., 2007. Spatial variability of aggregate-associated carbon and ni- trogen contents in the reclaimed minesoils of eastern Ohio. Soil Sci. Soc. Am. J. 71, 1748-1757.

Stanchi, S., Falsone, G., Bonifacio, E. 2015. Soil aggregation, erodibility, and erosion rates in mountain soils (NW Alps, Italy). Solid Earth, 6: 403-414.

Van Es, H.M., Ogden C.B., Hill R.L., Schindelbeck R.R. Tsegaye T., 1999. Integrated assessment of space, time, and management-related variability of soil hydraulic properties. Soil Sci. Soc. Am. J. 63, 1599-1608.

Webster, R., Oliver, M.A. 2007. Geostatistics for Environmental Scientists, second ed. John Wiley and Sons Ltd, Chichester.

Wischmeier, W.H., Mannering, J.V., 1969. Relation of soil properties to its erodibility. Soil Sci. Soc. Am. P. 33, 131-137.

Wuddivira, M.N., Camps-Roach, G., 2007. Effects of organic matter and calcium on soil structural stability. Eur. J. Soil Sci. 58, 722-727.

Zhang, B., Horn, R., 2001. Mechanisms of aggregate stabilization in Ultisols from subtropical China. Geoderma. 99, 123-145. 
Table 1: Descriptive statistics for the primary physical and chemical characteristics of the sampled soils.

\begin{tabular}{llllll}
\hline & Mean & SD & Median & Min. & Max. \\
\hline EC mmhos.cm-1 & 0.27 & 0.26 & 0.19 & 0.04 & 1.66 \\
Clay $\left(\mathrm{g} \cdot \mathrm{kg}^{-1}\right)$ & 329.0 & 186.7 & 294.0 & 46.0 & 747.0 \\
Silt $\left(\mathrm{g} \cdot \mathrm{kg}^{-1}\right)$ & 163.6 & 61.4 & 179.0 & 39.0 & 332.0 \\
Sand $\left(\mathrm{g} \cdot \mathrm{kg}^{-1}\right)$ & 507.4 & 229.6 & 520.0 & 41.0 & 909.0 \\
OC $\left(\mathrm{g} \cdot \mathrm{kg}^{-1}\right)$ & 10.4 & 4.6 & 9.7 & 2.1 & 28.0 \\
$\mathrm{~N}\left(\mathrm{~g} \cdot \mathrm{kg}^{-1}\right)$ & 0.9 & 0.4 & 0.9 & 0.3 & 2.3 \\
$\mathrm{pH}$ water & 8.3 & 0.3 & 8.3 & 6.7 & 9.0 \\
$\mathrm{CaCO3}\left(\mathrm{g} \cdot \mathrm{kg}^{-1}\right)$ & 67.7 & 88.3 & 30.0 & 1.0 & 375.0 \\
$\mathrm{CEC} \mathrm{cmol} . \mathrm{kg}^{-1}$ & 15.4 & 7.8 & 14.4 & 2.8 & 34.1 \\
Fe $\left(\mathrm{g} \cdot \mathrm{kg}^{-1}\right)$ & 10.7 & 5.2 & 9.2 & 2.4 & 22.6 \\
\hline
\end{tabular}

Table 2: Coefficients of correlation, $r$, between aggregate stability indexes and measured soil parameters.

\begin{tabular}{|c|c|c|c|c|c|c|c|c|c|c|c|c|c|}
\hline & $\mathrm{MWD}_{\mathrm{FW}}$ & $M_{W W}$ & $M W D_{M B}$ & $\mathrm{MWD}_{\text {mean }}$ & EC & Clay & Silt & Sand & $\mathrm{OC}$ & $\mathrm{N}$ & $\mathrm{pH}$ & $\mathrm{CaCO}_{3}$ & CEC \\
\hline $\mathrm{MWD}_{\mathrm{sw}}$ & $0.557^{* *}$ & & & & & & & & & & & & \\
\hline $\mathrm{MWD}_{\mathrm{MB}}$ & $0.504^{\star \star}$ & 0.650 ** & & & & & & & & & & & \\
\hline $\mathrm{MWD}_{\text {mean }}$ & $0.765^{\star \star}$ & $0.885^{\star \star}$ & $0.876^{\star \star}$ & & & & & & & & & & \\
\hline EC & -0.062 & -0.148 & 0.048 & -0.060 & & & & & & & & & \\
\hline Clay & $0.611^{\star *}$ & 0.450 ** & $0.584^{\star \star}$ & $0.638^{\star \star}$ & 0.048 & & & & & & & & \\
\hline Silt & $0.295^{\star \star}$ & $0.507^{* *}$ & $0.591^{\star *}$ & 0.569 ** & 0.106 & $\begin{array}{l}0.614^{\star *} \\
-\end{array}$ & - & & & & & & \\
\hline Sand & $-0.576^{\star *}$ & $-0.502^{\star \star}$ & $-0.633^{\star \star}$ & $-0.671^{\star *}$ & -0.067 & $0.977^{\star *}$ & $0.767^{* \star}$ & & & & & & \\
\hline $\mathrm{OC}$ & -0.093 & -0.020 & -0.096 & -0.080 & $0.396^{\star \star}$ & 0.047 & $0.343^{* *}$ & -0.130 & & & & & \\
\hline$N$ & -0.058 & 0.045 & 0.007 & 0.005 & $0.430^{\star *}$ & 0.149 & $0.443^{\star *}$ & $\begin{array}{l}-0.240^{*} \\
-\end{array}$ & $0.942^{\star \star}$ & & & & \\
\hline $\mathrm{pH}$ & 0.166 & $0.308^{\star \star}$ & $0.381^{\star \star}$ & $0.352^{\star \star}$ & 0.128 & $0.419^{\star *}$ & $0.443^{\star *}$ & $0.459 \star \star$ & 0.039 & 0.132 & & & \\
\hline $\mathrm{CaCO}_{3}$ & -0.162 & 0.056 & -0.080 & -0.061 & 0.043 & -0.113 & $0.232^{*}$ & $\begin{array}{l}0.030 \\
-\end{array}$ & $0.432^{\star \star}$ & $0.384^{\star *}$ & $0.267^{*}$ & & \\
\hline CEC & $0.581^{* *}$ & $0.407^{* *}$ & $0.513^{\star \star}$ & 0.579 ** & 0.062 & $0.973^{* *}$ & $0.653^{\star *}$ & $0.966^{\star \star}$ & 0.156 & $0.240^{*}$ & $0.389 * *$ & -0.114 & \\
\hline $\mathrm{Fe}$ & $0.588^{\star \star *}$ & $0.505^{\star \star}$ & 0.639 ** & $0.678^{\star \star}$ & 0.010 & $0.879 * \star$ & $0.565^{\star \star}$ & $0.866^{\star *}$ & -0.028 & 0.099 & $0.324^{\star *}$ & $-0.269 *$ & 0.828 \\
\hline
\end{tabular}

Significant at the level of $0.05\left(^{*}\right)$ and $0.01\left(^{(*)}\right.$.

Table 3: Comparison of prediction performance using RMSE, CVRMSE and CE criteria established through a leave-one-out cross-validation technique for the two tested methods.

\begin{tabular}{|c|c|c|c|c|c|c|}
\hline & \multicolumn{2}{|l|}{ RMSE } & \multicolumn{2}{|l|}{ CVRMSE } & \multicolumn{2}{|l|}{ CE } \\
\hline & Pedotransfer & $\begin{array}{l}\text { Regression- } \\
\text { kriging }\end{array}$ & Pedotransfer & $\begin{array}{l}\text { Regression- } \\
\text { kriging }\end{array}$ & Pedotransfer & $\begin{array}{l}\text { Regression- } \\
\text { kriging }\end{array}$ \\
\hline$M W D_{\mathrm{FW}}$ & 0.39 & 0.40 & 0.43 & 0.44 & 0.29 & 0.24 \\
\hline MWD & 0.55 & 0.49 & 0.31 & 0.27 & 0.27 & 0.42 \\
\hline$M W D_{\mathrm{MB}}$ & 0.49 & 0.52 & 0.40 & 0.42 & 0.47 & 0.41 \\
\hline$M W D_{\text {mean }}$ & 0.37 & 0.36 & 0.28 & 0.27 & 0.47 & 0.50 \\
\hline
\end{tabular}




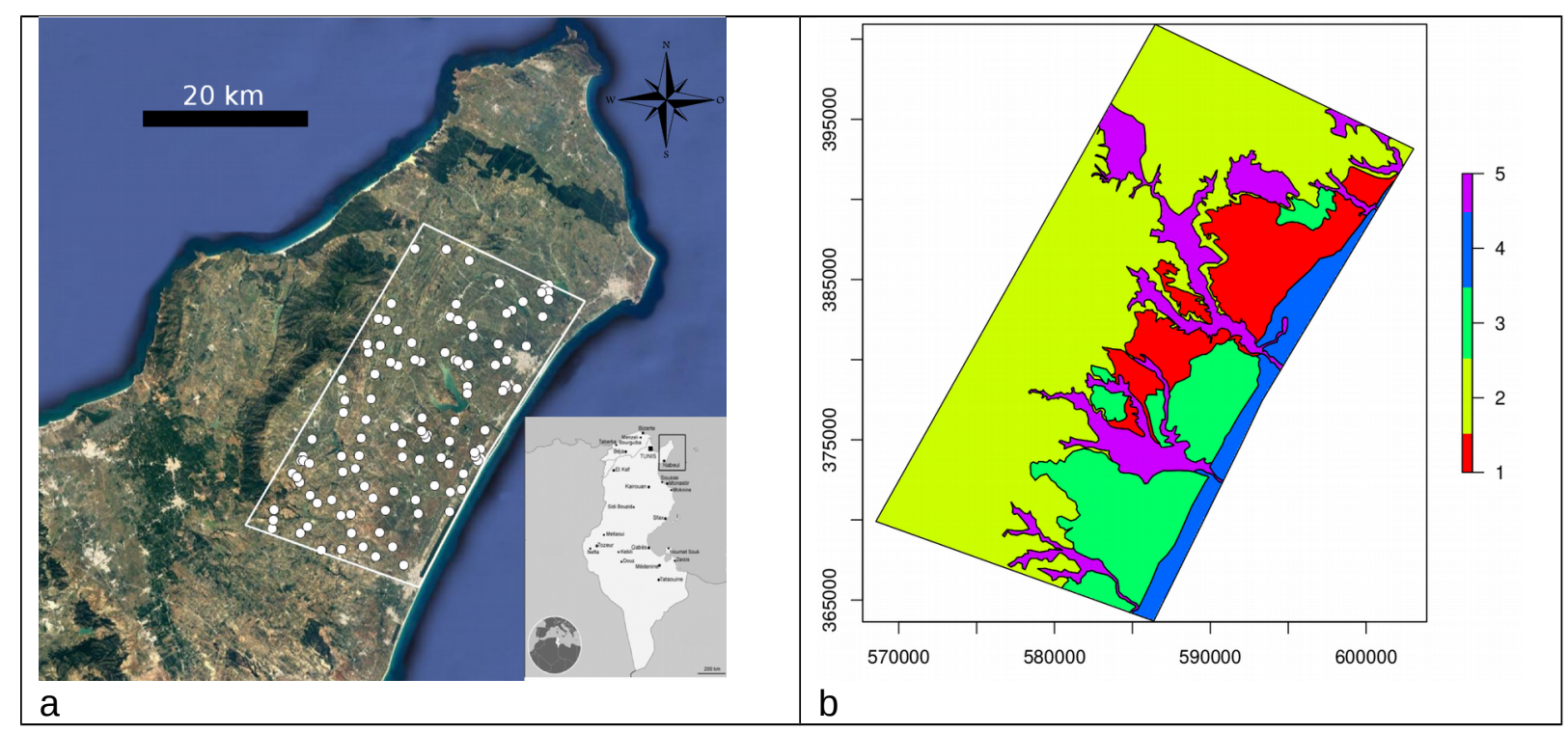

Fig. 1: a) Location of the study area in the Cap Bon region in northeastern Tunisia and those of the 113 soil samples (white dots). b) Geological information derived from the Tunisian geologic map 1/50000 (Bensalem, 1989) categorized into 5 geological units (1: alternation of soft-sandy layers and the thin layers of hard calcareous sandstone with Pliocene marine origin; 2: marls intercalated with Serravalian-Tortonian sandstone beds; 3: geological unit 1 encrusted with limestone; 4: recent coastal deposits; 5: recent and old terrestrial deposits near the wadis). $\mathrm{X}$ - and $\mathrm{Y}$-axes are Lambert Tunisian coordinates in meters. 


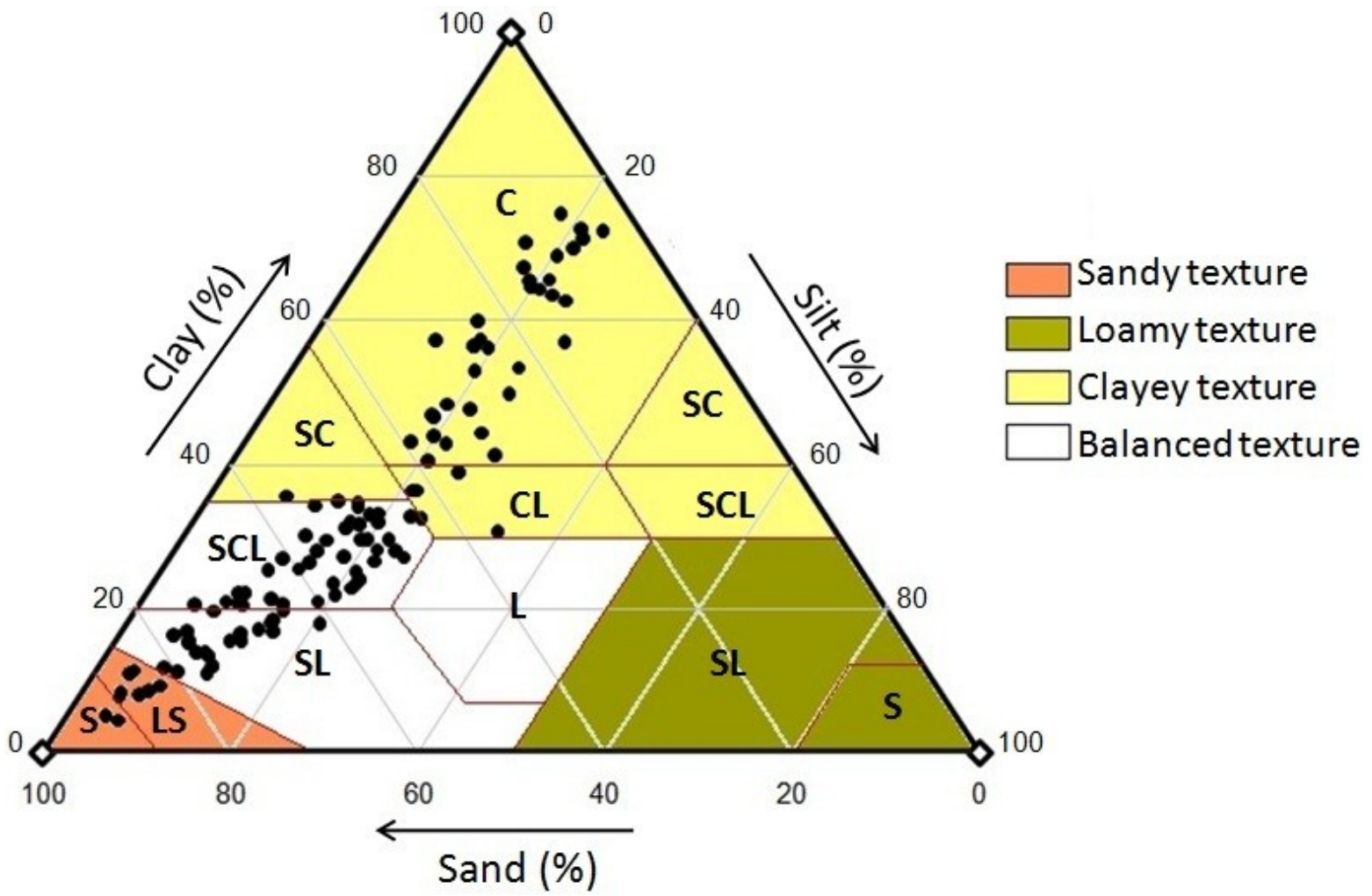

Fig. 2: Distribution of soil samples $(n=113)$ inside the texture triangle (S: sand, C: clay, S: silt, L: loam). 


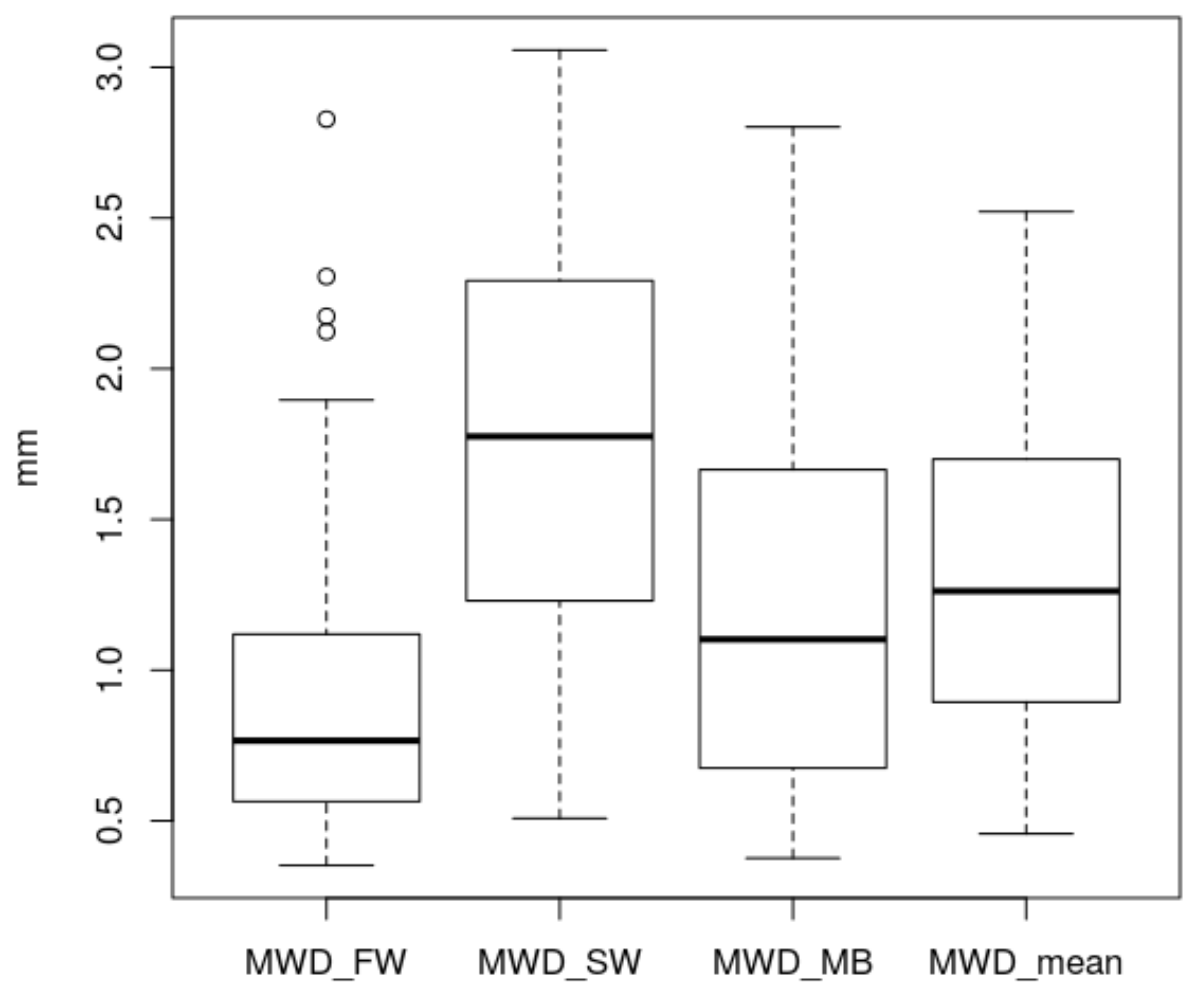

Fig. 3: Box plot of aggregate stability levels according to the three tests for the 113 soil samples.

(C) 2017. This manuscript version is made available under the CC-BY-NC-ND 4.0 license http://creativecommons.org/licenses/by-nc-nd/4.0/ 

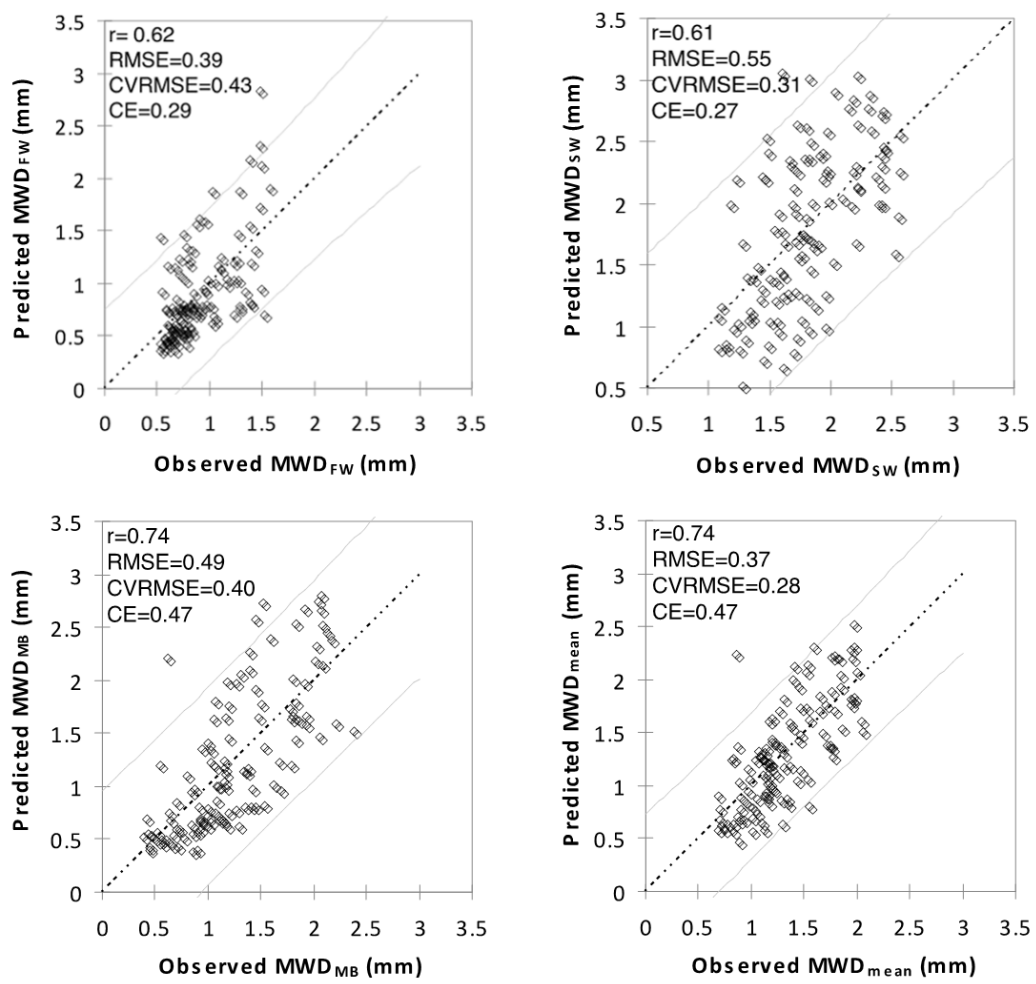

Fig. 4: Scatter plots of observed versus predicted MWD indexes using pedotransfer functions. Black line is the $x=y$ line, gray lines are the confidence limits $( \pm 95 \%)$. $r$ : regression coefficient, RMSE: root mean squared error, CVRMSE: normalized root mean squared error, CE: model efficiency. 

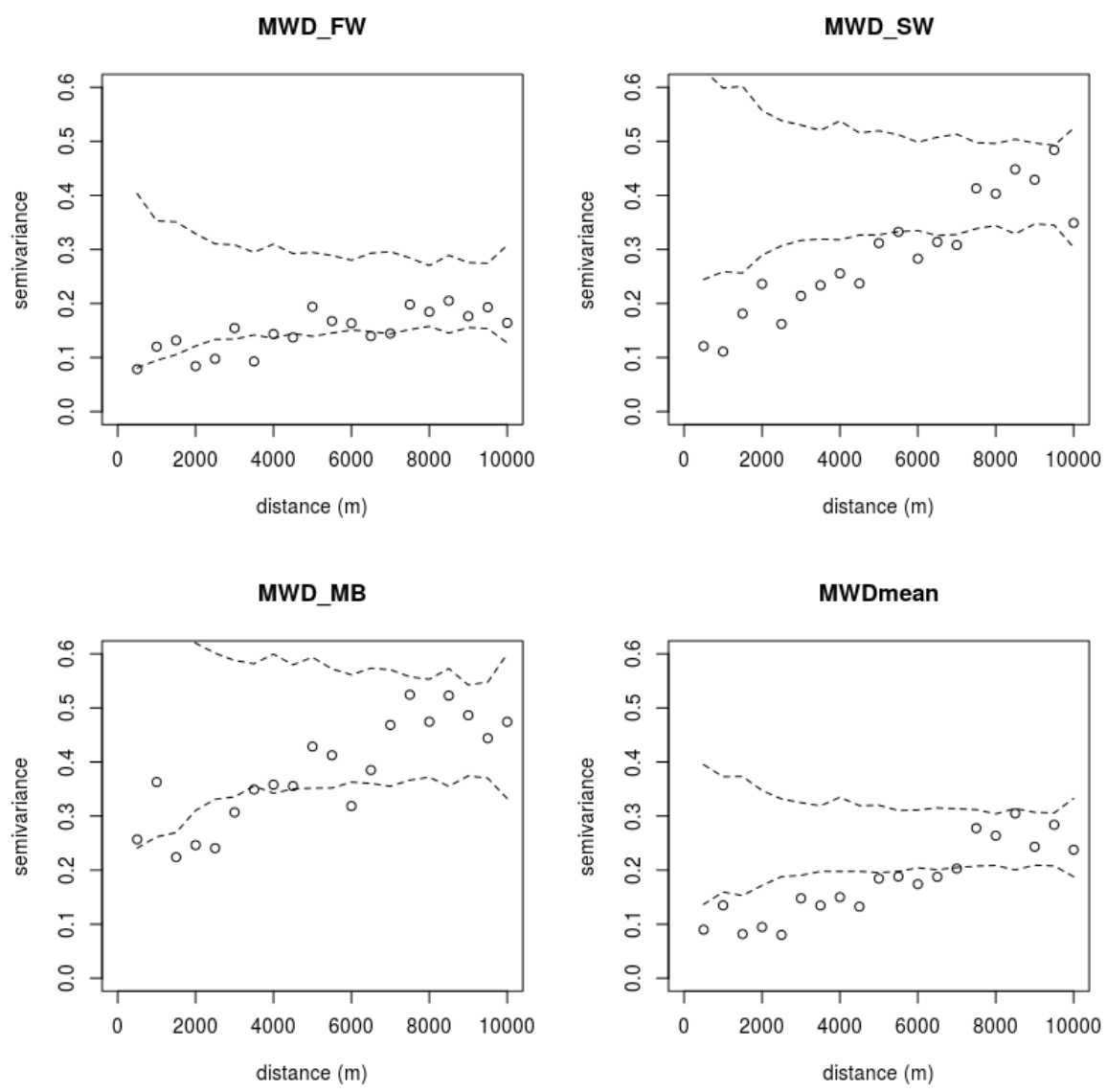

Fig. 5: Experimental semivariograms derived from MWD values for the 113 soil samples, and the envelopes (confidence $=95 \%$ ) obtained by permutation $\left(\mathrm{N}_{\text {sim }}=100\right)$ from the measured MWD. 

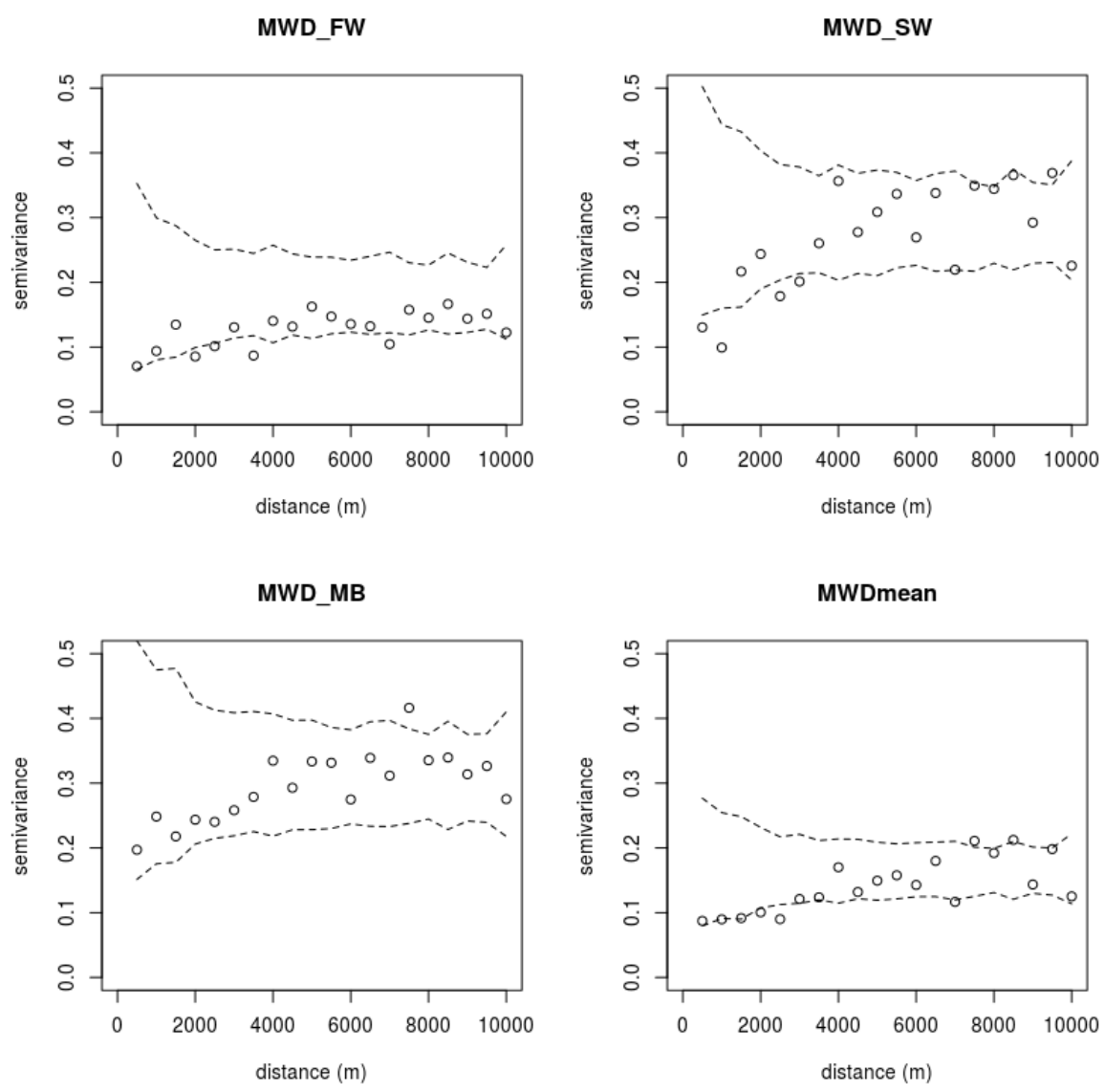

Fig. 6: Experimental semivariograms conducted on the residuals of the ANOVA prediction models of MWD indexes based on geological classes, and the confidence envelopes (95\%) obtained by permutation $\left(\mathrm{N}_{\mathrm{sim}}=100\right)$. 
a)
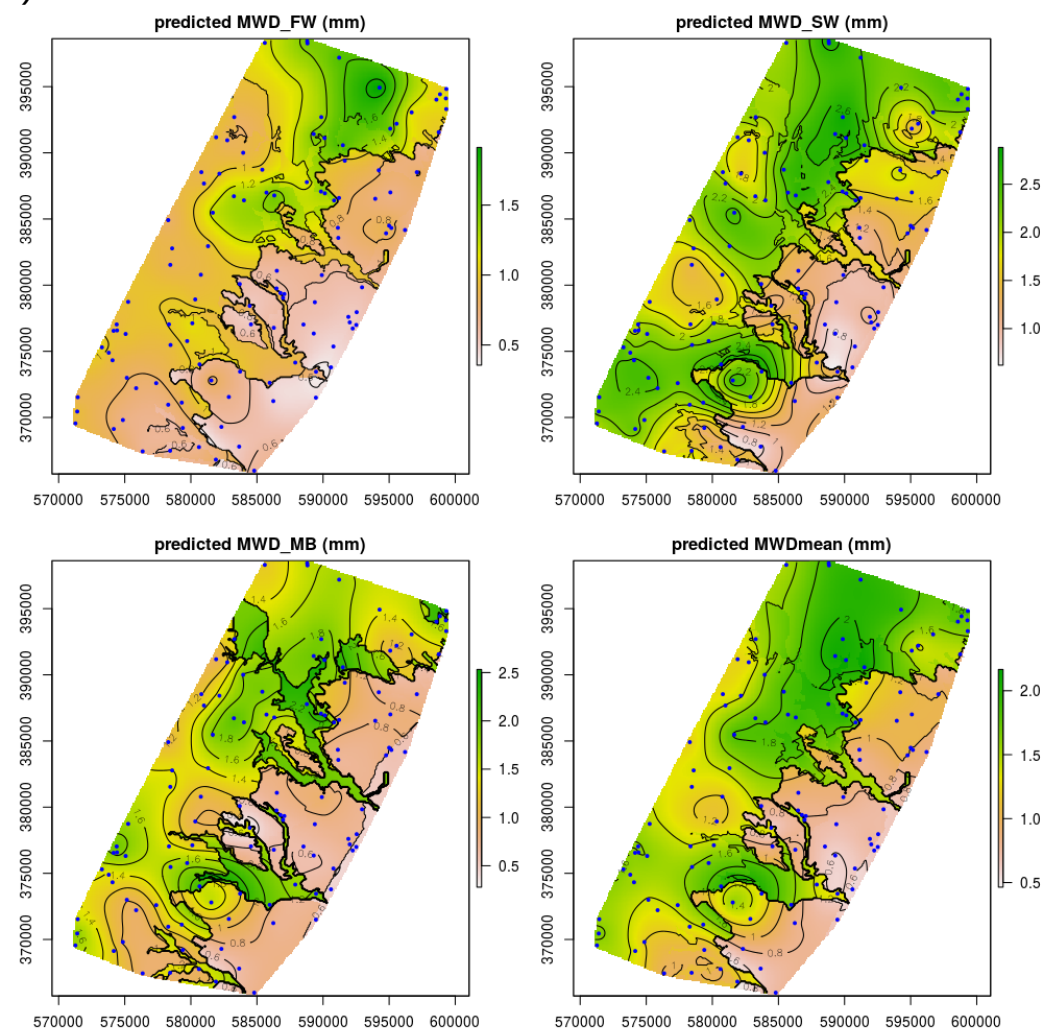

b)
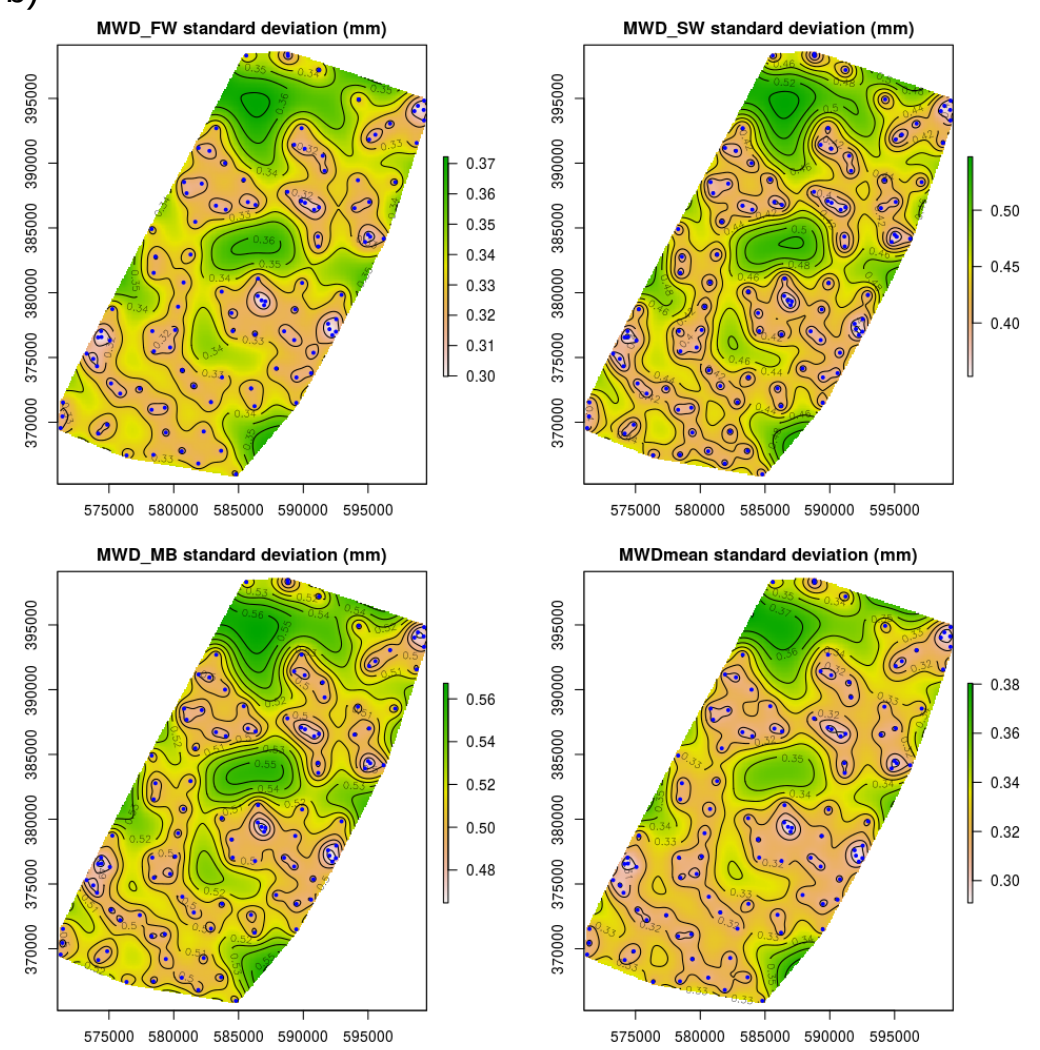

Fig. 7: Maps of a) the three MWD indexes and the average predicted by the regressionkriging approach, i.e., a combination of ANOVA based on geological information and krigeage prediction on the residuals values, and $b$ ) the associated standard deviations of these predictions. $\mathrm{X}$ - and $\mathrm{Y}$-axes are Lambert Tunisian coordinates in meters.

(c) 2017. This manuscript version is made available under the CC-BY-NC-ND 4.0 license http://creativecommons.org/licenses/by-nc-nd/4.0/ 